\title{
Hypervitaminemia B12: A Biological Marker yet to be Known
}

\author{
Zulfiqar Abrar-Ahmad*1 and Andres Emmanuel ${ }^{2}$ \\ ${ }^{1}$ Department of Geriatrics, University Hospital of Rouen, France \\ ${ }^{2}$ Department of Internal Medicine, University Hospital of Strasbourg, France
}

Submission: October 29, 2018; Published: November 16, 2018

*Corresponding author: Zulfiqar Abrar-Ahmad, M.D,MSc, Department of Geriatrics, Saint-Julien Hospital, University Hospital of Rouen, 76141 Le Petit Quevilly, France

\section{Introduction}

A high serum level of vitamin B12 (or cobalamin), also called hypervitaminemia B12 is a biological abnormality, yet one that is significantly underestimated. To date, no consensus on the management of this anomaly exists. According to the literature, high levels of vitamin B12 are associated or linked with a range of conditions, the majority of which are serious, with a systematic inquiry being decisive for prognosis following the discovery of a high serum cobalamin level [1-3].In clinical practice, the frequent occurrence of vitamin B12 deficiency, particularly in elderly patients, justifies systematic dosing with vitamin B12. A high serum cobalamin level, which appears to be even more common than vitamin B12 deficiency $[3,4]$, is therefore often discovered only fortuitously. Recent works have proposed that systematic etiological research as early etiological management is decisive for treatment outcomes [2,5,6].

\section{Metabolism of Vitamin B12 and Physiological Basis}

Vitamin B12 (Cobalamin) is an essential micronutrient that plays a fundamental role in cell division and one-carbon metabolism. Vitamin B12 is absorbed in the small intestine where the vitamin B12-intrinsic factor (IF) complex binds to a receptor, which is called cubam[7]. The source of vitamin B12 is exogenous, predominantly of animal origin. Many foods are a natural source of vitamin B12, because of bacterial symbiosis. It has been suggested that the current recommended daily intake for vitamin B12 may be inadequate to ensure genomic stability and that a vitamin B12 intake of $7 \mu \mathrm{g} /$ day, needed for a plasma level of $400 \mathrm{pg} / \mathrm{ml}$, would be more appropriate [8]. After ingestion of vitamin B12, its dissociation from its carrier proteins by gastric acid and pancreatic secretions is an essential prerequisite for the binding of vitamin B12 to the IF secreted by gastric parietal cells [9]. The vitamin B12-IF complex reaches the terminal ileum, where absorption of vitamin B12 occurs. The transport of vitamin B12 in the blood, as well as its tissue and hepatic uptake, require the presence of transcobalamin (TCB) [10].
Serum B12 is bound to both transcobalamin (TCB) and haptocorrin (HC). These partly saturated (holo) and partly unsaturated (apo) with B12 proteins circulate in the blood. TCB I and TCB III ensure the binding of $80 \%$ of circulating vitamin B12; however, TCB II plays the important role in the key processes of tissue and hepatic uptake of vitamin B12. Holotranscobalamin II is composed of vitamin B12 attached to TCB II, and it represents the biologically active fraction that can be delivered into all DNA synthesizing cells. Liver storage of vitamin B12 is mediated by endothelial cells, hepatocytes being naturally devoid of TCB II receptors [1]. TCB saturated with B12 (holo-TCB) constitutes 6 to $20 \%$ of endogenous circulating B12. In contrast, HC binds $\sim 80-94 \%$ of the endogenous plasma B12 (holo-HC), and is largely saturated with B12 or analogs [11].

\section{Hypervitaminemia B12: Prognostic Marker?}

An association between hypervitaminosis B12 and solid neoplasms was demonstrated in a study of vitamin B12 and haptocorrin levels in a population of 139 individuals with malignant disease [12]. The main relevant cancers are hepatocellular carcinoma (HCC) and secondary liver tumors, breast cancer, colon cancer, stomach cancer, and pancreatic tumors [1]. Pathophysiologically, in solid tumors, hypervitaminosis B12 is mainly linked to excessive synthesis of transcobalamins by the tumor or high haptocorrin levels due to leukocytosis reaction [1]. Hypervitaminosis B12 has also been described as a potential tumor marker of poor prognosis [13].A previous study [14] found strong predictive value for mortality for hypervitaminosis B12 in individuals with cancer receiving palliative care. A study of the prognosis of people with cancer and hypervitaminosis B12 found a strong association between hypervitaminosis B12 and poor prognosis, with a median survival of approximately 1 month.

Metastases were also more frequent in this subgroup [15]. Likewise, another study found greater mortality associated with high levels of vitamin B12 in a series of 1,570 individuals 
aged 65 and older admitted to a geriatric ward [16] It has been suggested that vitamin B12 levels be used as a tool in investigative and therapeutic decision-making, especially in severely ill individuals or those with chronic disease [15]. Prognostic value has been attributed to vitamin B12 in cancer, and an index, the vitamin B12/CRP Index (BCI), has been developed that has a high predictive value for mortality in cancer in palliative care (P $<$.001) [15]. A BCI greater than 40,000 was associated with $90 \%$ mortality at 3 months. The highest rate was associated with the highest mortality [15]. A study of 329 individuals with advanced cancer confirmed these findings, with 29-day median survival in those with a BCI greater than 40,000 $(\mathrm{P}<.01)$ [17].

The BCI should be considered as an additional prognostic indicator, alongside the PPS [18] and the PPI [19]. The PPI consists of a weighted scale assessing five clinical variables (performance status, oral intake, edema, dyspnea at rest, delirium) [19]. These two instruments do not include clinician estimates as an independent prognostic factor. Moreover, BCI does not rely on subjective estimates of symptom severity or clinician estimates of survival.

\section{Conclusion}

Further exploratory studies are warranted to explore serum vitamin $\mathrm{B} 12$ and the $\mathrm{BCI}$ as a tool in investigative and therapeutic decision-making and to develop new prognostic scales for elderly adults.

\section{Conflict of Interest}

The author declares no conflict of interest.

\section{References}

1. Andrès E, Serraj K, Zhu J, Vermorken AJM (2013) The pathophysiology of elevated vitamin B12 in clinical practice. QJM 106(6): 505-515.

2. Chiche L, Jean R, Romain F, Roux F, Thomas G, et al. (2008) Implications cliniques de la découverte d'une hypervitaminémie B12 en médecine interne. Rev Médecine Interne 29(3):187-194.

3. Deneuville T, Mario N, Tiev KP, Tolédano C, Josselin-Mahr L, et al. (2009) Concentration plasmatique élevée de la vitamine B12 : un indicateur des maladies hépatiques ou tumorales? Rev Médecine Interne 34(6): 337-341.

4. Chiche L, Mancini J, Arlet JB (2009) Hypervitaminémies B12 en médecine interne : résultats de l'étude BDOSE. Rev Médecine Interne 30(4): S377.

5. Serraj K, Mecili M, Housni I, Andrès E (2011) High level of cobalamin: physiopathology, role and interest in clinical practice. Presse Médicale
40(12 Pt 1):1120-1127.

6. Rochat MC, Vollenweider P, Waeber G (2012) Hypervitaminémie B 12: implications cliniques et prise en charge. Rev Médicale Suisse 8(360):2072-2076.

7. Fyfe FC, Madsen M, Hojrup P, Christensen EI, Tanner SM, et al. (2004) The functional cobalamin (vitamin B12)-intrinsic factor receptor is a novel complex of cubilin and amnionless. Blood 103(5): 1573-1579.

8. Solomon LR (2007) Disorders of cobalamin (vitamin B12) metabolism: emerging concepts in pathophysiology, diagnosis and treatment. Blood Rev 21(3):113-130.

9. Andres E, Vidal-Alaball J, Federici L, Loukili NH, Zimmer J, et al. (2007) Clinical aspects of cobalamin deficiency in elderly patients. Epidemiology, causes, clinical manifestations, and treatment with special focus on oral cobalamin therapy. Eur J Intern Med 18(6): 456462.

10. Ermens AA, Vlasveld LT, Lindemans J (2003) Significance of elevated cobalamin (vitamin B12) levels in blood. Clin Biochem 36(8): 585-590.

11. Bowen RA, Dowdell KC, Dale JK, Drake SK, Fleisher TA, et al. (2012) Elevated vitamin $B_{12}$ levels in autoimmune lymphoproliferative syndrome attributable to elevated haptocorrin in lymphocytes. Clin Biochem 45(6): 490-492.

12. Carmel R (1975) Extreme elevation of serum transcobalamin I in patients with metastatic cancer. N Engl J Med 292(6): 282-284.

13. Arendt JFB, Pedersen L, Nexo E, Sorensen H (2013) Elevated plasma vitamin B12 Levels as a marker for cancer: A population-based cohort study. J Natl Cancer Inst 105(23):1799-1805.

14. Kane SP, Murray-Lyon IM, Paradinas FJ, Johnson PJ, Williams R, et al. Vitamin B12 binding protein as a tumour marker for hepatocellular carcinoma. Gut 19(12): 1105-1109.

15. Geissbuhler P, Mermillod B, Rapin CH (2000) Elevated serum vitamin B12 levels associated with CRP as a predictive factor of mortality in palliative care cancer patients: A prospective study over five years. J Pain Symptom Manage 20(2): 93-103.

16. Tal S, Shavit Y, Stern F, Malnick (2010) Association between vitamin B12 levels and mortality in hospitalized older adults. J Am Geriatr Soc 58(3): 523-526.

17. Kelly L, White S, Stone PC (2007) The B12/CRP index as a simple prognostic indicator in patients with advanced cancer: A confirmatory study. Ann Oncol 18(8): 1395-1399.

18. Pirovano M, Maltoni M, Nanni O, Marinari M, Indelli M, et al. (1999) A new palliative prognostic score: A first step for the staging of terminally ill cancer patients. Italian Multicenter and Study Group on Palliative Care. J Pain Symptom Manage 17(4): 231-239.

19. Morita T, Tsunoda J, Inoue S, Chihara S (1999) The Palliative Prognostic Index: A scoring system for survival prediction of terminally ill cancer patients. Support Care Cancer 7(3): 128-133. 
(C) This work is licensed under Creative CC (i) Commons Attribution 4.0 License DOI: 10.19080/PMCIJ.2018.01.555553

\section{Your next submission with Juniper Publishers} will reach you the below assets

- Quality Editorial service

- Swift Peer Review

- Reprints availability

- E-prints Service

- Manuscript Podcast for convenient understanding

- Global attainment for your research

- Manuscript accessibility in different formats

( Pdf, E-pub, Full Text, Audio)

- Unceasing customer service

Track the below URL for one-step submission https://juniperpublishers.com/online-submission.php 